\title{
MORPHOMETRIC STUDY OF PTERION IN DRY ADULT HUMAN
} SKULLS

\section{Pratima Kulkarni ${ }^{1}$, Shivaji Sukre ${ }^{2}$, M runal Muley ${ }^{*}$.}

${ }^{1}$ Associate Professor, Department of Anatomy, G.M.C. Aurangabad, M aharashtra, India.

2 Professor and Head of department, Department of Anatomy, G.M.C. Aurangabad, M aharashtra, India.

${ }^{* 3}$ Assistant Professor, Department of Anatomy, G.M.C. Aurangabad, M aharashtra, India.

\section{ABSTRACT}

Introduction: The pterion corresponds to the site of anterolateral fontanelle of the neonatal skull which closes at third month after birth. In the pterional fractures the anterior and middle meningeal arterial ramus ruptures commonly which results in extradural hemorrhage. Pterional approach is most suitable and minimally invasive approach in neurosurgery.

Materials and M ethods: The present study was carried out on the pterion of 36 dry adult skulls of known sex from department of anatomy GM CAurangabad M aharashtra.

Results: The mean and standard deviation of the distance between the centre of pterion to various anatomical landmarks. The distance between Pterion- frontozygomatic (P-FZ) suture $29.81 \pm 4.42 \mathrm{~mm}$ on right side, $29.81 \pm 4.07 \mathrm{~mm}$ on left side; Pterion-Zygomatic arch (P-Z) $37.16 \pm 3.77 \mathrm{~mm}$ on right side, $37.56 \pm 3.71 \mathrm{~mm}$ on left side, Pterion-asterion (P-A) $89.73 \pm 6.16 \mathrm{~mm}$ on right side, $89.46 \pm 6.35 \mathrm{~mm}$ on left side; Pterion-external acoustic meatus (P-EAM) $53.40 \pm 7.28 \mathrm{~mm}$ on right side, $53.57 \pm 6.73 \mathrm{~mm}$ on left side, Pterion- $M$ astoid process (P-M ) $80.35 \pm 3.44 \mathrm{~mm}$ on right side, $80.96 \pm 3.79 \mathrm{~mm}$ on left side and Pterion- Pterion (P-P) $194.54 \pm 16.39 \mathrm{~mm}$ were measured.

Conclusion: The data constructed in the present study will be of immense importance while performing pterional approach surgeries in Indian population.

KEY WORDS: Pterion, Fontanelle, Neonatal Skull, Extradural Hemorrhage, Pterional Approach.

Address for Correspondence: Dr. M runal K Muley, Assistant Professor, Department of Anatomy, G.M.C. Aurangabad, M aharashta, India.

E-Mail: mrunal.137@gmail.com

\section{Access this Article online}

\section{Quick Response code}

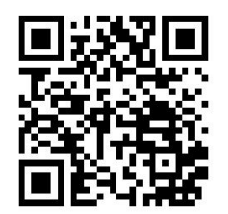

DOI: $10.16965 /$ ijar.2017.337

Web site: International Journal of Anatomy and Research

ISSN 2321-4287

www.ijmhr.org/ijar.htm

Received: 07 Jul 2017

Peer Review: 08 Jul 2017

Revised: None
Accepted: 16 Aug 2017

Published (0): 30 Sep 2017

Published (P): 30 Sep 2017

\section{INTRODUCTION}

Pterion is defined as an $\mathrm{H}$-shaped small circular area formed by the junction of four bones: frontal, parietal, temporal and sphenoid on norma lateralis of the skull, being approximately $4 \mathrm{~cm}$ above the zygomatic arch and $3.5 \mathrm{~cm}$ behind frontozygomatic suture [1].

The pterion corresponds to the site of anterolateral fontanelle of the neonatal skull which closes at third month after birth [2]. According M oore $\&$ Dalley [3] reported that the pterion is two fingers' breadth superior to the zygomatic arch and a thumb's breadth posterior to the frontal process of the zygomatic bone.

Pterion is an important guide for age and sex determination as well as archaeological and Forensic estimation. It is also an important site to assess anterior branch of middle meningeal 
artery, Broca's area, sphenoid ridge and optic canal [4].

In the pterional fracures the anterior and middle meningeal arterial ramus ruptures commonly which results in extradural hemorrhage. Pterional approach is most suitable and minimally invasive approach in neurosurgery. It is used to access to structures of anterior and middle cranial fossae. ${ }^{2}$ Pterional approaches have paved the way for the management of wide variety of neurological disorders in the anterior, middle and upper part of posterior cranial fossa with minimal tissue injury, without compromising surgical results [5]. So proper knowledge of pterion, its topography and morphology is mandatory for the pterional approach used in the neurosurgery.

This morphometric analysis will be of immense importance while performing pterional approaches in neurosurgical procedures in Indian population.

\section{MATERIALS AND METHODS}

The present study was carried out on the pterion of 36 dry adult skulls of known sex. The skulls with pathological lesions and damage were excluded. Samples were collected from department of anatomy GMC Aurangabad Maharashtra.

Material used for taking measurement Digital Vernier Caliper, cotton thread, scale. For the measurement of the distance of pterion from different bony landmarks, the centre of pterion was first established. Readings were taken twice and mean of two readings was taken to avoid error.

\section{Following measurements were studied}

Pterion- frontozygomatic suture (P-FZ): Distance from centre of to the posterolateral aspect of the frontozygomatic suture.

Pterion-Zygomatic arch (P-Z): The distance from the centre of pterion to the superior edge of the midpoint of zygomatic arch.

Pterion - asterion (P-A): The distance between centre of pterion and at asterion.

Pterion- external acoustic meatus (P- EAM): The distance between centre of pterion to the anteriosuperior margin of external acoustic meatus.

Int J Anat Res 2017, 5(3.3):4365-68. ISSN 2321-4287
Pterion- Mastoid process (P-M): The distance between pterion to the tip of the mastoid process.

Pterion- Pterion (P-P): Distance between two pterions.

The distance between Pterion-frontozygomatic (P-FZ) suture, Pterion-Zygomatic arch (P-Z), Pterion-asterion (P-A), Pterion-external acoustic meatus (P-EAM), Pterion- $M$ astoid process (P-M) were measured with the help of Digital Vernier caliper. Distance between two pterions was measured with the help of cotton thread and measuring scale.

Fig. 1: Distance between pterion and frontozygomatic suture (P-FZ).

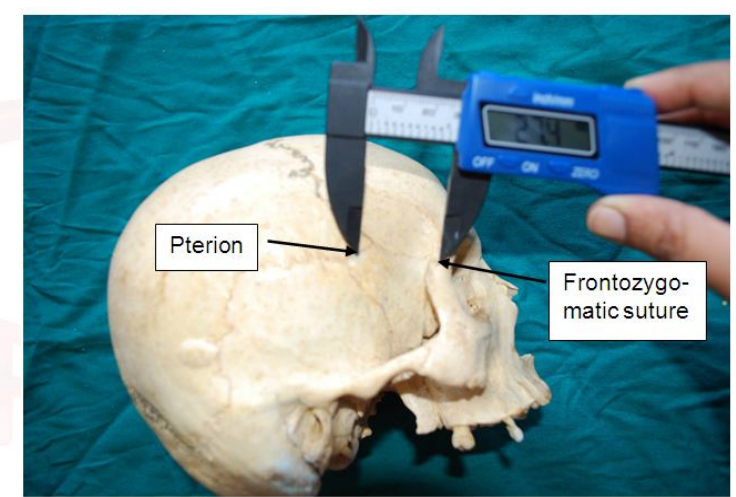

Fig. 2: Distance between pterion and middle of the zygomatic arch (P-ZA).

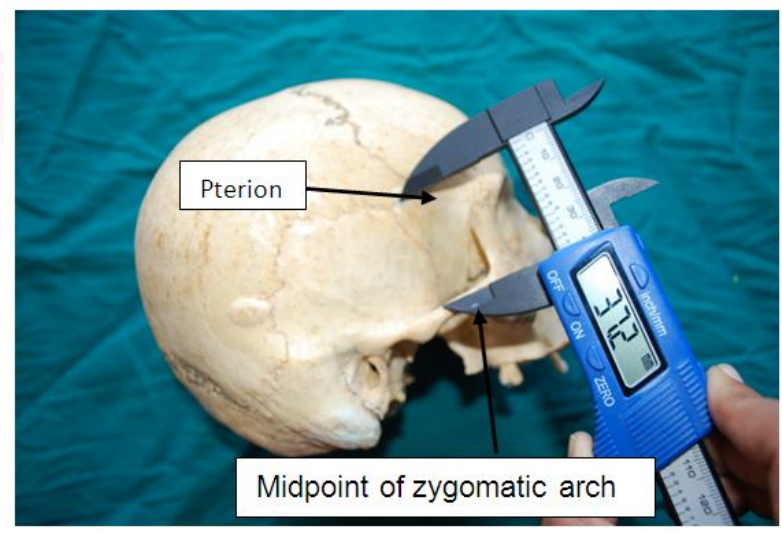

Fig. 3: Distance between pterion and anterosuperior margin of external acoustic meatus (P-EAM).

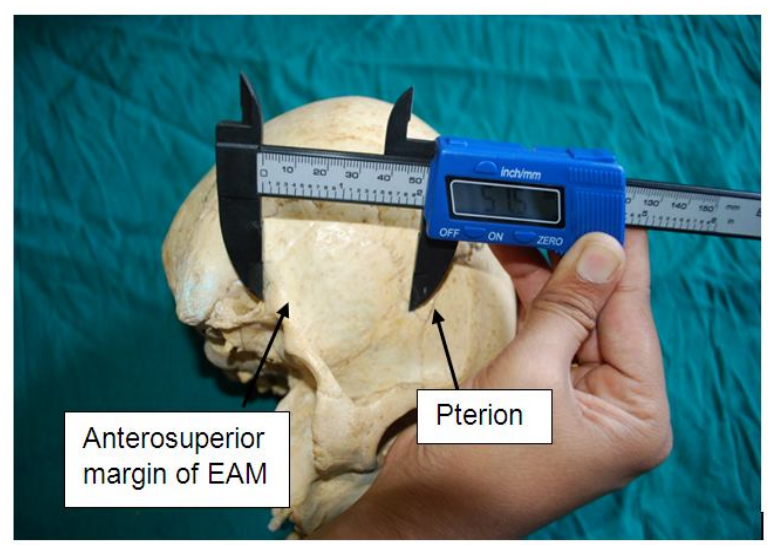


Fig. 4: Distance between pterion and asterion (P-A).

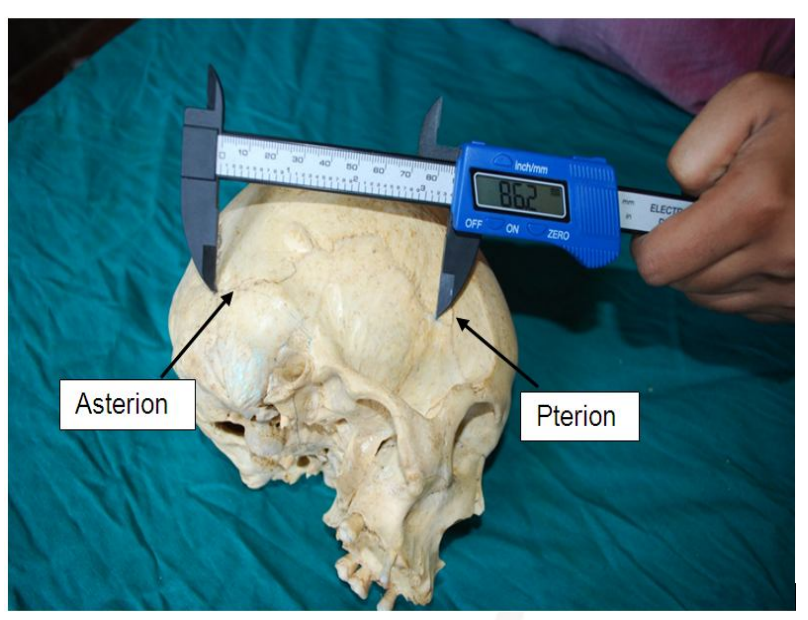

\section{OBSERVATION AND RESULTS}

The distance between Pterion-frontozygomatic (P-FZ) suture, Pterion-Zygomatic arch (P-Z), Pterion-asterion (P-A), Pterion-external acoustic meatus (P-EAM), Pterion- $M$ astoid process (P-M) were measured to determine the location of pterion.

The mean and standard deviation of the distance between the centre of pterion to various anatomical landmarks are tabulated as follows:

Table 1: Distance of pterion from various bony landmarks.

\begin{tabular}{|c|c|c|c|}
\hline Sr. no. & PARAM ETERS & $\begin{array}{c}\text { Right } \\
\text { (mean } \pm \text { SD) in } \mathrm{mm}\end{array}$ & $\begin{array}{c}\text { Left (mean } \pm \text { SD) } \\
\text { in mm }\end{array}$ \\
\hline 1 & $\begin{array}{c}\text { The distance between Pterion- } \\
\text { frontozygomatic (P-F) }\end{array}$ & $29.81 \pm 4.42$ & $29.81 \pm 4.07$ \\
\hline 2 & $\begin{array}{c}\text { The distance between Pterion- } \\
\text { Zygomatic arch (P-Z) }\end{array}$ & $37.16 \pm 3.77$ & $37.56 \pm 3.71$ \\
\hline 3 & $\begin{array}{c}\text { The distance between Pterion - } \\
\text { asterion (P-A) }\end{array}$ & $89.73 \pm 6.16$ & $89.46 \pm 6.35$ \\
\hline 4 & $\begin{array}{c}\text { The distance between Pterion- } \\
\text { external acoustic meatus (P. EAM) }\end{array}$ & $53.40 \pm 7.28$ & $53.57 \pm 6.73$ \\
\hline 5 & $\begin{array}{c}\text { The distance between Pterion- } \\
\text { Mastoid process (P-M) }\end{array}$ & $80.35 \pm 3.44$ & $80.96 \pm 3.79$ \\
\hline 6 & $\begin{array}{c}\text { The distance between Pterion- } \\
\text { Pterion (P.P) }\end{array}$ & \multicolumn{2}{|c|}{$194.54 \pm 16.39$} \\
\hline
\end{tabular}

No significant variation on right and left side was observed in various parameters measured from the centre of pterion.

\section{DISCUSSION}

Pterional approach was considered as the minimally invasive neurosurgical approach ideal for anterior and middle cranial fossa lesion [6]. The location of pterion and its relation to the surrounding bony landmarks is important. Such detailed information can only precisely be obtained from an examination of dry Skulls.
Mishra et al [1] found that the mean distance $P$-EAM was $5.12 \mathrm{~cm}$ on right side, $5.19 \mathrm{~cm}$ on left side; P-M was $8.13 \mathrm{~cm}$ on right side and $8.02 \mathrm{~cm}$ on left side. K Epharaim Vikram Rao et al [2] observed that the distances of centre of pterion from midpoint of zygomatic arch (P-FZ) was $37.74 \pm 3.66$ on right side, $37.07 \pm 4.19$ on left side; $P-F$ was $30.48 \pm 4.06$ on right side, $30.39 \pm 4.70$ on left side; P-EAM was $51.81 \pm 4.080$ n right side, $51.54 \pm 3.89$ on left side and $P-M$ was $80.40 \pm 6.43$ on right side and $79.68 \pm 6.08$ on left side.

Table 2: Comparison between distances of centre of pterion from different bony landmarks in previous studies and present study.

\begin{tabular}{|l|c|c|c|c|}
\hline \multicolumn{1}{|c|}{ Comparative studies } & \multicolumn{2}{|c|}{$\begin{array}{c}\text { The distance between } \\
\text { Pterion-Zygomatic } \\
\text { arch (P-Z) (cm) }\end{array}$} & \multicolumn{2}{|c|}{$\begin{array}{c}\text { The distance between } \\
\text { Pterion-Zygomatic } \\
\text { arch (P-FZ) (cm) }\end{array}$} \\
\hline & $\mathrm{R}$ & $\mathrm{L}$ & $\mathrm{R}$ & $\mathrm{L}$ \\
\hline Mishra et al (2015) [1] & 3.71 & 3.68 & 3.2 & 3.11 \\
\hline Oguz et al (2004) [7] & 4.05 & 3.85 & 3.3 & 3.44 \\
\hline Mwachaka et al (2009) [8] & 3.888 & 3.824 & 3 & 3 \\
\hline Adejuwon et al (2013) [9] & 3.91 & 3.877 & 3.1 & 3.082 \\
\hline Sowmya Set al (2017) [10] & 4.02 & 3.99 & 3.42 & 3.33 \\
\hline Apinhasmit et al (2011) [11] & 3.848 & 3.848 & 3.112 & 3.112 \\
\hline Ukohla et al (2013) [12] & 4.02 & 4.01 & 2.74 & 2.74 \\
\hline Kumar S. et al (2013) [13] & 3.76 & 3.76 & 3.25 & 3.35 \\
\hline Eboh and Obaroefe (2014) [14] & 4.02 & 3.95 & 3.2 & 3.1 \\
\hline Present study & 3.71 & 3.75 & 2.98 & 2.98 \\
\hline
\end{tabular}

Results of current study are in line with M ishra et al ${ }^{1}$ and K Epharaim Vikram Rao ${ }^{2} \mathrm{M}$ wachaka et al [8] Apinhasmit et al [11] Kumar S. et al [13] Whereas mean values of present study are slightly less than those of Oguz et al [7], Ukohla et al [12] and Eboh and Obaroefe [14].

\section{CONCLUSION}

The present study concludes that the location of pterion in relation to different bony landmarks are important in neurosurgeries or mini-craniotomy while approaching anterior or middle cranial fossa. Such detailed information can readily be obtained from morphometric study of dry skulls. However, as imaging techniques continue to develop, it may be possible to determine more precise relationships between bony landmarks and the underlying soft tissues. The data constructed in the present study will be of immense importance while performing pterional approach surgeries in Indian population. 


\section{ABBREVIATIONS}

P-FZ - Distance between Pterion-frontozygomatic suture

P-Z - Distance between Pterion-Zygomatic arch

P-A - Distance between Pterion-asterion

P-EAM - Distance between Pterion-external acoustic meatus

P-M - Distance between Pterion- Mastoid process

\section{Conflicts of Interests: None}

\section{REFERENCES}

[1]. M ishra PP, Hari Prasad, N. K. Bezbaruah, Anshu M ishra. M orphometric analysis of pterion: A clinicanatomical study in north Indian dry skulls. Innovative Journal of M edical and Health Science, [S.I.], 20115;5(5). ISSN 2277-4939.

[2]. KEphraim Vikram Rao, B Sadananda Rao, B H Shiny Vinila. Morphology and M orphometric Analysis of Pterion with its Neurosurgical Implications in Pterional Approach. Int J Anat Res 2017;5(1):33843388.

[3]. Moore, K. L. \& Dalley, A. F. Clinical Oriented Anatomy.5th ed. Philadelphia, Lippincott Williams \& Wilkins, 2006;887- 903.

[4]. Pavan P. Havaldar, Shruthi B.N, Shaik Hussain Saheb, HenjarappaK S. M orphological Study on Shapes of Pterion. Int J Anat Res 2015;3(4):1555-1558.

[5]. Seema D, Dakshayani K.R., Sumanth M.M. A M orphometric Study of Pterion in Adult Human Skulls. International Journal of Recent Trends and Technology. 2013;9(4):112-115.

[6]. Cheng WY, Lee HT, Sun MH, Shen CC. A pterion keyhole approach for the treatment of anterior circulation aneurysms. Minim Invasive Neurosurg. 2006;9: 257-262.

[7]. Oguz O, Sanli SG, Bozkir M G, Soames RW. The pterion in Turkish male skulls. Surg Radiol Anat 2004;26:220-224

[8]. M wachaka PM, Hassanali J, Odula P. Sutural morphology of pterion and asterion among adult Kenyans. Braz J M orpholo Sci 2009;26:4-7

[9]. Adejuwon SA, Olopade FE, Bolaji M. Study of location and morphology of pterion in adult Nigerian skulls. ISRN Anatomy, 2013;4.
[10]. Sowmya S, M eenakshi B, Priya Ranganath. Study of pterion: Its clinical and morphological aspects. Indian journal of Clinical Anatomy and Physiology, 2017:4(2):247-249.

[11]. Apinhasmit W., Chompoopong S., Chaisuksunt V., Thiraphatthanavong P., Phasukdee N. Anatomical consideration of pterion and its related references in Thai dry skulls for pterional surgical approach, Journal Of The Medical Association Of Thailand Chotmaihet Thangphaet. 2011;94(2):205-214.

[12]. Ukoha U., Oranusi C.K., Okafor J.I., Udemezue 0.0., Anyabolu A.E., Nwamarachi T.C. Anatomic study of the pterion in Nigerian dry human skulls, Nigerian Journal of Clinical Practice, 2013;16(3):325-328.

[13]. Kumar S., Anurag, M unjal S., Chauhan P., Chaudhary A., Jain S. K. Pterion its location and clinical implications- A Study Compared. Journal of Evolution of Medical and Dental Sciences 2013;12(25):45994608.

[14]. Eboh D. E. O. \& Obaroefe M. M orphometric study of pterion in dry human skull bones of Nigerians, Int. J. Morphol., 2014;32(1):208-213.

[15]. T. M urphy. The pterion in the Australian aborigine. The American Journal of Physical Anthropology. 1956;14(2):225-244.

[16]. Urzi F., lannello A., Torrisi, A., Foti, P., M ortellaro, N.F., Cavallaro, M. M orphological variability of pterion in the human skull. Ital. J. Anat. Embryol.2003; 108:83-117.

[17]. Ankur Zalawadia, Jignesh Vadgama, Srushti Ruparelia, Shailesh Patel, S. P. Rathod, S. V. Patel. Morphometric Study of Pterion in Dry Skull of Gujarat Region. NJIRM . 2010;1(4):25-29.

[18]. Walulkar S, Dehankar R, Walulkar M, Ksheersagar DD. Pterion formation and its variations in Human Skull in Vidarbha Region. J Cont Med A Dent.2016 ;4(2):58-61.

[19]. Saxena R., Bilodi A., M ane S., Kumar A. Study of pterion in skulls of Awadh area-in and around Lucknow. Kathmandu University Medical Journal, 2003;1(1):32-33.

[20]. M anjunath K.Y. \& Thomas I.M. Pterion variants and epipteric ossicles in South Indian skulls, J Anat Soc India, 1993;42:85-94.

How to cite this article:

Pratima Kulkarni, Shivaji Sukre, M runal Muley. M ORPHOM ETRIC STUDY OF PTERION IN DRY ADULT HUM AN SKULLS. Int J Anat Res 2017;5(3.3):4365-4368. DOI: 10.16965/ ijar.2017.337 